\title{
Targeting the T Helper 2 Inflammatory Axis in Atopic Dermatitis
}

\author{
Adriana S. Moreno ${ }^{a}$ Roderick McPhee ${ }^{b}$ Luisa Karla Arruda ${ }^{a}$ \\ Michael D. Howell ${ }^{b}$ \\ ${ }^{a}$ Department of Medicine, Ribeirão Preto Medical School, University of São Paulo, Ribeirão Preto, Brazil; \\ b Medlmmune, LLC, Gaithersburg, MD, USA
}

\section{Keywords}

Atopic dermatitis · Atopic eczema - Immunoglobulin E . Monoclonal antibodies · Allergy · Hypersensitivity · Pruritus

\begin{abstract}
Atopic dermatitis (AD) is a chronic inflammatory skin disease that affects up to $25 \%$ of children and $10 \%$ of adults. The skin of patients with moderate to severe $A D$ is characterized by significant barrier disruption and T helper 2 (Th2)-driven inflammation, which are thought to play a significant role in the pathogenesis of AD. Current management of AD is aimed at suppressing the inflammatory response and restoring the barrier function of the skin, reducing exacerbations, and preventing secondary skin infections. Combinations of treatment strategies are used to alleviate the symptoms of the disease; however, resolution is often temporary, and long-term usage of some of the medications for AD can be associated with significant side effects. Antibody therapies previously approved for other inflammatory diseases have been evaluated in patients with AD. Unfortunately, they have often failed to result in significant clinical improvement. Monoclonal antibodies and novel small molecules currently in development may provide more consistent benefit to patients with $A D$ by specifically targeting the immune and molecular pathways important for the pathogenesis of AD. Here we review the state-of-the-art therapeutics targeting the Th2 axis in AD.
\end{abstract}

(c) 2016 S. Karger AG, Basel

\section{KARGER}

(C) 2016 S. Karger AG, Basel

E-Mail karger@karger.com

www.karger.com/iaa

\section{Introduction}

Atopic dermatitis $(\mathrm{AD})$ is a chronic inflammatory skin disease affecting up to $25 \%$ of children and approximately $10 \%$ of adults [1-5]. Although most patients develop AD before the age of 5 years, $9-17 \%$ of patients may not develop AD until adulthood [6-8]. For many children, the onset of $\mathrm{AD}$ marks the beginning of a progression from $\mathrm{AD}$ to food allergy, allergic rhinitis, and eventually asthma, a scenario frequently described as the "atopic march" $[9,10]$. On the other hand, many children outgrow their $\mathrm{AD}$ before adolescence, indicating that the "atopic march" is not an inevitable course. However, studies focusing on disease onset during infancy and early childhood might overestimate the percentage of children who outgrow their $\mathrm{AD}$ if there is not adequate follow-up during the teen years and adulthood [11]. Likewise, asthma and food allergy can disappear as the child grows older $[12,13]$. Data on the progression from $\mathrm{AD}$ to asthma over the last 3 decades reveal that this phenomenon appears to depend on a variety of factors including early-life wheezing, allergic sensitization, and the sex of the patient $[14,15]$. Van der Hulst et al. [16], in their systematic review of prospective cohort studies involving the relationship of early AD to subsequent childhood asthma, observed an increased risk (odds ratio 2.14; 95\% confidence interval 1.67-2.75) of developing asthma following early onset AD. More recently, the Prevention of Allergy 
among Children in Trondheim study demonstrated an increased risk (odds ratio 3.07; 95\% confidence interval 1.79-5.27) of asthma at the age of 6 years in those patients who had developed AD by the age of 2 years [17]. Recently, a genome-wide association study demonstrated a significant overlap between the susceptibility loci for $\mathrm{AD}$ and asthma [18], further supporting the link between early-onset $\mathrm{AD}$ and asthma [19].

The skin of patients with moderate to severe $\mathrm{AD}$ is characterized by widespread lesions, which manifest as erythematous areas with crusting and/or scaling, oozing, excoriations, and lichenification. Pruritus is one of the major symptoms of the disease and may be severe, causing sleep disturbance [20]. Altogether, these symptoms may lead to a profound impact on the patient's self-esteem and quality of life $[21,22]$. The skin is characterized by a predominant T helper 2 (Th2) environment, which, combined with the itching and resulting mechanical disruption of the skin barrier, plays a central role in the pathogenesis of the disease. Most patients with AD present with increased serum immunoglobulin $\mathrm{E}$ (IgE) levels, blood eosinophilia, and allergen sensitization, as a result of increased Th2 pathway activation [23]. Chronic AD lesions display a mixed $\mathrm{Th} 1$ and $\mathrm{Th} 2$ response, and the release of IL-22 from Th17 and Th22 cells in AD skin samples has been reported. Increased levels of IL-22 in chronic $\mathrm{AD}$ lesions compared with the levels in acute lesions suggest that a transition from Th17 to Th22 is associated with chronic disease [24]. Therefore, AD might be considered a Th2/Th22-skewed disease, with an additional contribution from Th1 cytokines occurring in the chronic stages [25]. In addition, loss of function mutations in the gene coding for filaggrin (FLG), an important protein involved in skin barrier integrity, have been reported in subsets of patients with AD [26]. FLG mutations have been identified as a strong risk factor for $\mathrm{AD}$, and might lead to a distinct AD endotype, characterized by earlyonset $\mathrm{AD}$ that is more persistent and often associated with development of asthma, food allergy, and IgE sensitization $[27,28]$. However, the majority of patients with $\mathrm{AD}$ do not have FLG mutations, and, in these patients, the downregulation of epidermal FLG expression may be caused by several important factors including Th2 skin inflammation and environmental conditions related to pruritus-induced mechanical damage [27]. The mechanisms by which scratching of the skin may lead to decreased FLG expression are not fully understood. It has been proposed that acute barrier changes, such as those resulting from scratching, can disrupt the calcium gradient which exists in normal epidermis. This gradient is characterized by ascending calcium levels from the basal to the granulosa epidermal layers, and a subsequent decrease across the stratum corneum. Reduced calcium levels in the stratum granulosum due to scratching could then lead to the downregulation of FLG expression [27]. Another important issue is whether secondary FLG deficiency due to Th2 inflammation, environmental stressors such as low humidity, mechanical trauma due to scratching and other factors, is transient or is a permanent event. Evidence for this being a transient effect may come from the investigation of therapies focused on the restoration of FLG expression [29,30]. A candidate compound, JTC801, which is a 4-aminoquinoline derivative, was able to increase FLG mRNA expression in both a human immortalized keratinocyte cell line and in normal human epidermal keratinocytes. JTC801 also increased expression of FLG in a human skin-equivalent model, and attenuated atopic skin inflammation in mice in vivo [30]. Another compound, a Janus kinase (JAK) inhibitor, JTE-052, induced FLG expression and decreased the development of $\mathrm{AD}$-like lesions in mice [31]. Finally, coal $\operatorname{tar}$ (a traditional topical therapeutic agent for AD) was shown to contain polycyclic aromatic hydrocarbons (PAHs), which activate the aryl hydrocarbon receptor (AHR) signaling pathway, increasing the expression of FLG. Enhanced activation of the AHR signaling pathway by deacetylase sirtuin 1 (SIRT1) has also been shown to promote FLG expression in a mouse model [32]. Taken together, these studies indicate that it may be possible to increase FLG expression, suggesting that secondary FLG deficiency may be reversible, with therapeutic implications for patients with $\mathrm{AD}$.

Given its prevalence and impact on the quality of life of patients, effective treatment strategies are needed for patients with moderate to severe $\mathrm{AD}$. Current treatment recommendations include the liberal use of emollients, wet-wrap therapy, vitamin D supplementation, topical calcineurin inhibitors, and topical corticosteroids (TCS) $[1,33,34]$. When moisturizers alone are not sufficient to control the itch and inflammation, TCS are the mainstay of treatment for AD. Although effective, TCS may be associated with adverse effects, including skin atrophy and increased susceptibility to infections, which are directly related to the potency and the duration of use. Judicious use of high-potency preparations of TCS, avoiding thinskin areas such as the face or skin folds and minimizing the duration of treatment, is critical [33]. Unfortunately, therapy with TCS alone may not be effective for patients with moderate to severe disease $[35,36]$. Allergen immunotherapy is now a consideration in selected patients with 
Fig. 1. Targeting IL-4- and IL-13-mediated signaling. IL-4 and IL-13 signaling involves both distinct and overlapping receptors, which results in similar downstream pathway activation. IL-4 signals through the type I receptor, comprising the common $\gamma$ chain and IL-4R $\alpha$, and the type II receptor, comprising IL-4Ra and IL-13Ra1. IL-13 predominantly signals through the type II receptor but also binds to the decoy receptor IL-13Ra2 with high affinity. Pitrakinra (mutein protein) specifically binds to IL$4 \mathrm{Ra}$ while dupilumab (monoclonal antibody) prevents IL-4 and IL-13 signaling through IL-4Ra. Additionally, lebrikizumab and tralokinumab are monoclonal antibody therapies that specifically target IL-13. By signaling through their respective receptors, both IL-4 and IL-13 activate the JAK/STAT pathway, inducing the transcription of inflammatory mediators. Tofacitinib and baricitinib are chemical compounds which inhibit JAK activation. IL, interleukin; JAK, Janus kinase; STAT, signal transducer and activator of transcription.

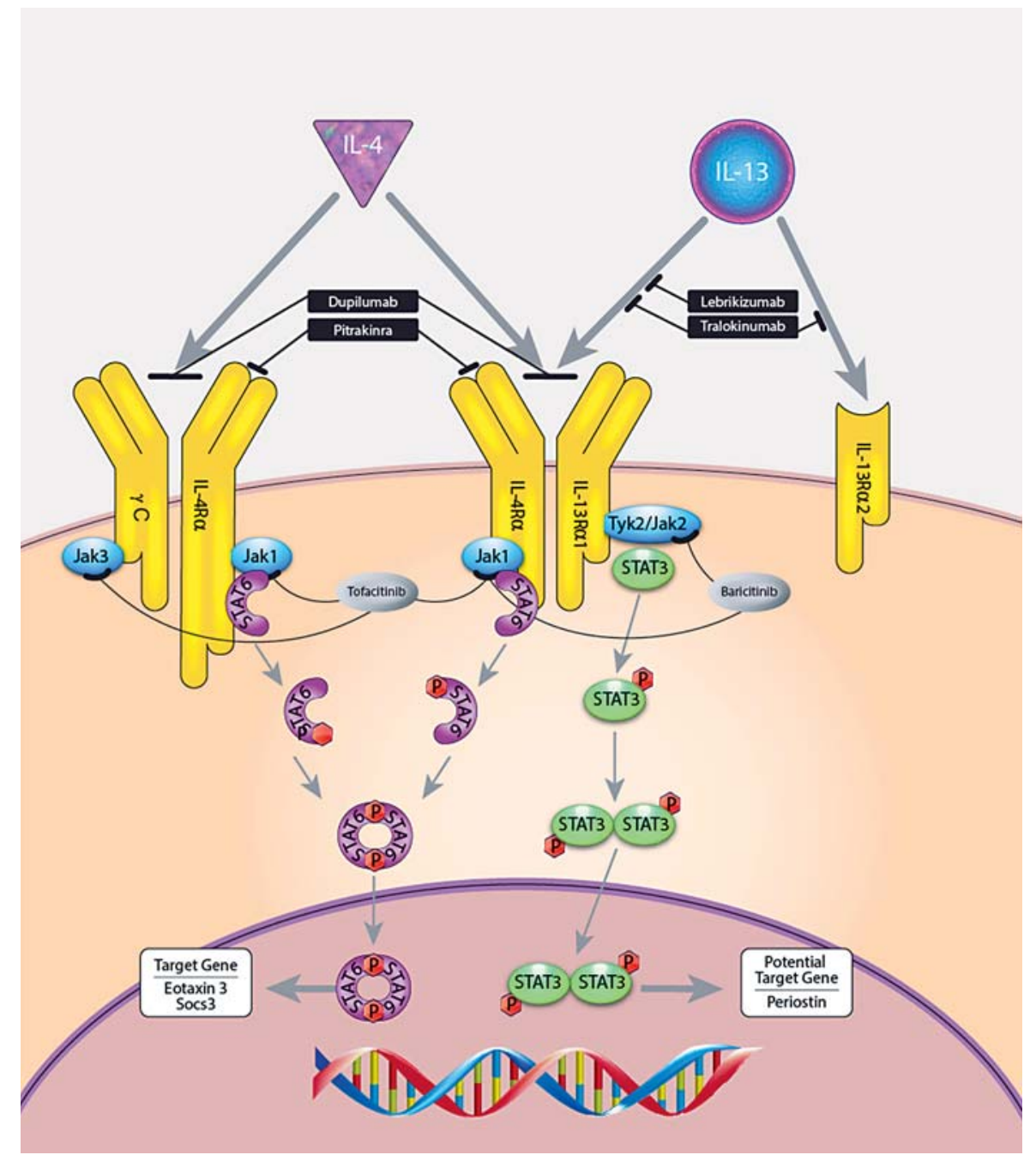

$\mathrm{AD}$ and aeroallergen sensitization [37]. Phototherapy and systemic immunosuppressant therapies including systemic corticosteroids, cyclosporine, methotrexate, mycophenolate mofetil, and azathioprine, may be used in patients with severe disease refractory to conventional therapy; however, these therapies are associated with significant, potentially serious side effects $[1,33,37,38]$.

Novel therapeutic approaches which target the pathways involved in the pathogenesis of $\mathrm{AD}$ provide the opportunity for a potentially more effective and less harmful approach to systemic therapy. The number of clinical trials evaluating the novel chemical and biological agents specifically targeting pathways and mechanisms in $\mathrm{AD}$ has steadily increased in recent years and may provide options for patients in the near future. In this review, we will discuss therapeutic approaches for targeting the Th2 axis in moderate to severe AD.

\section{The Role of Dominant Th2 Cytokines in AD}

The Th2 cytokines, IL-4, IL-5, and IL-13, play a central role in the pathogenesis of $\mathrm{AD}$ by activating inflammatory pathways in multiple cell types, impairing epidermal barrier structure and function, and inducing allergen sensitization [39].

Studies have previously reported increased IL-4 and IL-13 expression in acute and chronic skin lesions of patients with $\mathrm{AD}$ [40-42], and recently demonstrated increased numbers of CD4- and CD8-positive cells in circulation that secrete IL-4 and IL-13 [43]. The critical role of Th2 cells in AD was recently demonstrated in a study by Czarnowicki et al. [44], who found significant expansion of Th2 cell frequencies in cutaneous lymphocyte-associated antigen-positive (CLA+) T cells of adult patients with moderate to severe $\mathrm{AD}$, compared with healthy con- 
trols. Interestingly, the study also revealed reduced numbers of CLA+ Th1 cells, compared with healthy controls. The increased frequency of Th2 cells, particularly within the CLA+ T cell population, suggests that these Th2 cells and the cytokines they produce are an integral part of the pathogenesis of moderate to severe $\mathrm{AD}$.

Preclinical studies performed on transgenic mice further illustrate the central role of IL-4 or IL-13 in AD pathogenesis. Transgenic mice overexpressing epidermal IL-4 spontaneously developed signs and symptoms associated with $\mathrm{AD}$, including epidermal thickening and lesion formation, as well as elevated IgE levels [45]. Similarly, transgenic mice expressing IL-13 in the skin developed intense pruritus in addition to increased $\operatorname{IgE}$ production, epidermal thickening, and cellular-infiltration characteristics of $\mathrm{AD}$ [46]. In a murine model of IL-4, IL-5, and IL-13, investigators further demonstrated a positive correlation between the onset and progression of AD-like disease and the expression of these Th2 cytokines [47]. IL-4 and IL-13 signal through a common receptor, IL-4Ra, a requisite receptor to induce the signal transducer and activator of transcription 6 (STAT6)/JAK signaling cascade (Fig. 1). Mice genetically modified to constitutively express active STAT6 develop AD-like disease that is reversed by antibodies against either IL- 4 or IL-13 [48], suggesting that interfering with this pathway could be efficacious in patients with $\mathrm{AD}$.

IL- 4 and IL-13 drive the pathogenesis of disease by modulating several key immunological features including the inhibition of integral barrier proteins such as FLG, loricrin, and involucrin, and the destabilization of tight junctions [49-52], leading to the enhanced penetration of allergens and pathogens. Additionally, downstream signaling of IL- 4 and IL-13 has been shown to prevent the induction of innate immune response genes, such as $\beta$-defensins and cathelicidin $[41,53,54]$, thereby increasing the susceptibility of patients to Staphylococcus aureus and herpes simplex virus skin infections $[55,56]$.

Pitrakinra is a recombinant human IL- 4 mutein that specifically binds to IL-4Ra (Fig. 1), thereby inhibiting the downstream signaling of both IL-4 and IL-13 [57]. Initial studies using pitrakinra in asthma demonstrated a positive clinical effect, as demonstrated by reduced airway inflammation [58], prompting further exploration in $\mathrm{AD}$. The therapeutic effect of pitrakinra in AD was evaluated in a phase 2, double-blind, placebo-controlled study (NCT00676884; Table 1) on 25 patients; however, the results from the trial, completed in 2006, have not yet been published. Dupilumab also binds to IL-4Ra, therefore blocking both the IL-4 and IL-13 signaling pathways
(Fig. 1). Although these 2 compounds may share the ability to prevent IL-4 and IL-13 signaling, their structures and modes of action are very different. Pitrakinra was developed by creating mutations in the IL- 4 molecule, conferring the ability to antagonize the activation of IL4-R $\alpha$, whereas dupilumab is a fully human monoclonal antibody that specifically targets IL-4Ra and blocks downstream signaling by preventing the dimerization of IL$4 \mathrm{R} a$ with IL-13R $\alpha 1$ or the $\gamma$ chain. In recent years, dupilumab has demonstrated clinical efficacy in multiple phase 1 , phase 2 , and phase 3 clinical studies in patients with moderate to severe AD (Table 1) [59, 60]. In 2014, Beck et al. [59] reported that weekly treatment with dupilumab monotherapy $(300 \mathrm{mg})$ for 12 weeks reduced skin disease severity, as measured by the Eczema Area Severity Index (EASI), by $74.0 \%$, compared with $23.3 \%$ with placebo. Additionally, dupilumab-treated patients observed an almost $60 \%$ reduction in the body surface area affected, and $40 \%$ of patients achieved disease clearance (Investigator's Global Assessment score of 0 or 1) at day 85. Furthermore, patients treated with dupilumab experienced significantly fewer skin infections ( 0.05 infections per patient) than patients treated with placebo ( 0.20 infections per patient). Usage of TCS in addition to dupilumab provided even greater clinical benefit. Recently, a larger phase $2 \mathrm{~b}$ clinical trial was conducted to evaluate a dose response and different dosing frequencies of dupilumab. Thaçi et al. [60] confirmed the therapeutic benefit of weekly dosing with $300 \mathrm{mg}$ of dupilumab $(-73.7 \pm 5.2 \%$ change in EASI from baseline), but additionally observed improved skin scores with alternative dosing regimens of $200 \mathrm{mg}$ every other week $(-65.4 \pm 5.2 \%), 300 \mathrm{mg}$ every other week $(-68.2 \pm 5.2 \%)$, and $300 \mathrm{mg}$ every 4 weeks $(-63.5 \pm 4.9 \%)$. Skin improvement in each cohort additionally corresponded with a reduction in the pruritus score and the body surface area affected. These data demonstrate the consistent therapeutic benefit of targeting the IL-4/IL-13 axis with dupilumab for individuals with moderate to severe AD. Additional clinical trials are currently evaluating the therapeutic benefit of targeting IL-13 alone in $\mathrm{AD}$, using the monoclonal antibodies tralokinumab and lebrikizumab (Table 1).

IL-5 is a Th2 cytokine that plays a critical role in eosinophil differentiation, activation, and proliferation [61, 62]. Eosinophils play a significant role in allergic inflammation and have previously been shown to be elevated in both the circulation and lesional skin of patients with $\mathrm{AD}$ [63]. Similarly, levels of IL-5 are significantly elevated in the lesional skin of patients with $\mathrm{AD}$ and the levels in the circulation correlate with increased serum IgE [42]. UsDOI: $10.1159 / 000451083$
Moreno/McPhee/Arruda/Howell 
Table 1. Interventional studies in $\mathrm{AD}$ targeting the Th2 axis

\begin{tabular}{|c|c|c|c|c|c|}
\hline \multirow[t]{2}{*}{ CRTH2 } & OC000549 & Atopix & NCT02002208 & oral & \\
\hline & QAW039 & Novartis & NCT01785602 & oral & \\
\hline $\mathrm{IgE}$ & omalizumab & $\begin{array}{l}\text { Hoffman-La Roche/ } \\
\text { Genentech }\end{array}$ & NCT01179529 & subcutaneous & $86-95$ \\
\hline \multirow[t]{2}{*}{ IL-4R $\alpha$} & $\begin{array}{l}\text { REGN668/ } \\
\text { SAR231893/ } \\
\text { dupilumab }\end{array}$ & Regeneron/Sanofi & $\begin{array}{l}\text { NCT01259323 } \\
\text { NCT01385657 } \\
\text { NCT01548404 } \\
\text { NCT01639040 } \\
\text { NCT01859988 } \\
\text { NCT01949311 } \\
\text { NCT01979016 } \\
\text { NCT02210780 } \\
\text { NCT02260986 } \\
\text { NCT02277743 } \\
\text { NCT02277769 } \\
\text { NCT02395133 } \\
\text { NCT02407756 }\end{array}$ & subcutaneous & $22,59,60,102$ \\
\hline & $\begin{array}{l}\text { AER001/BAY16-9996/ } \\
\text { pitrakinra }\end{array}$ & Aerovance & NCT00676884 & subcutaneous & 57,58 \\
\hline IL-5 & mepolizumab & GlaxoSmithKline & & subcutaneous & 65,66 \\
\hline IL-13 & $\frac{\text { tralokinumab }}{\text { lebrikizumab }}$ & $\begin{array}{l}\text { AstraZeneca/MedImmune } \\
\text { Hoffmann-La Roche/ } \\
\text { Genentech }\end{array}$ & $\begin{array}{l}\text { NCT02347176 } \\
\text { NCT02340234 } \\
\text { NCT02465606 }\end{array}$ & $\begin{array}{l}\text { subcutaneous } \\
\text { subcutaneous }\end{array}$ & \\
\hline JAK1/JAK3 & tofacitinib & Pfizer & NCT02001181 & oral & 76 \\
\hline JAK1/JAK2 & $\begin{array}{l}\text { baricitinib } \\
\text { (LY3009104/INCB028050) }\end{array}$ & Eli Lilly/Incyte & NCT02576938 & oral & \\
\hline
\end{tabular}

ing a murine model of allergic inflammation, knocking out IL-5 resulted in reduced numbers of infiltrating eosinophils and epidermal thickening following exposure to allergens [64], suggesting a potential application for IL-5 blockade in patients with AD (Table 1). Interestingly, the administration of mepolizumab, a fully humanized monoclonal antibody targeting IL-5, did not significantly reduce skin disease severity or pruritus in patients with $\mathrm{AD}$, despite reducing the eosinophils in the circulation by approximately $60 \%$ [65]. Investigators further demonstrated that treatment with mepolizumab failed to significantly reduce the size of the reactions and the tissue eosinophils in patients with AD during the atopy patch test [66]. These results suggest that a reduction of circulating eosinophils is insufficient to significantly modulate AD disease severity. Additional therapies targeting the IL-5 axis (i.e. reslizumab and benralizumab) are currently un-

Targeting the Th2 Axis in AD der investigation for the treatment of eosinophilic asthma, and could be evaluated for their ability to prevent the migration of eosinophils into the skin and the subsequent disease improvement. This has potential to be tailored towards personalized medicine for patients with moderate to severe $\mathrm{AD}$ and elevated baseline eosinophils.

\section{Targeting the Th2-Associated Epithelial Cytokine Thymic Stromal Lymphopoietin}

Thymic stromal lymphopoietin (TSLP) was initially identified in a mouse thymic stromal cell line and is largely produced by epithelial cells in response to microbial invasion or tissue injury [67]. TSLP and TSLP receptor (TSLPR) are elevated in the lesional skin of patients with $\mathrm{AD}[68,69]$ and mediate signaling through dendritic cells 
to promote Th2 cell maturation and allergic responses. Targeted overexpression of TSLP in the keratinocytes of transgenic mice is associated with an $\mathrm{AD}$-like phenotype, including increased Th2 cytokine expression and serum IgE levels [70]. Additionally, studies have demonstrated that TSLP triggers IL-5 induction and eosinophil recruitment [71], and that the TSLP-induced AD phenotype in mice is $\mathrm{T}$ cell-dependent but not IL-4-/IL-13-dependent [72]. In addition to an immunomodulatory role, TSLP has been shown to directly induce an itching response by signaling through sensory neurons [73]. These studies suggest that TSLP has the potential to drive AD pathogenesis in both a Th2-dependent and independent manner while also inducing the "itch cycle." Tezepelumab and MK8226 are antagonists targeting the TSLP signaling pathway in clinical trials in patients with moderate to severe $\mathrm{AD}$ (Table 1).

\section{Targeting the JAK/STAT Signaling Axis}

IL-4, IL-5, IL-13, and TSLP signal through their respective receptors to induce downstream signaling events through the JAK/STAT pathway. Specifically, IL-4 and IL-13 engage with IL-4Ra and either the $\gamma$ chain or IL$13 \mathrm{R} \alpha 1$ to induce JAK 1 and JAK3, leading to the activation of STAT6 (Fig. 1). IL-5 engages with the IL-5R and $\beta$ chain to induce JAK1 and JAK2, leading to STAT1, STAT2, and STAT5 activation [74]. TSLP binds to a heterodimeric receptor comprising TSLPR and IL-7 receptor alpha (IL-7Ra) to induce JAK1 and JAK2 expression, leading to STAT5 activation [75]. JAK inhibitors provide the opportunity to prevent the downstream signaling of multiple Th2 cytokines, and are currently being evaluated in patients with moderate to severe $\mathrm{AD}$ (Table 1). Tofacitinib targets JAK1and JAK3, and is currently approved for the treatment of rheumatoid arthritis and is under evaluation in additional inflammatory diseases. Topical administration of tofacitinib to patients with mild to moderate $\mathrm{AD}$ was evaluated in a recently completed phase 2 clinical trial, but the results have not been published (NCT02001181; Table 1). Oral tofacitinib administration was recently evaluated in 6 patients with moderate to severe $\mathrm{AD}$, with promising results. Investigators observed a $66 \%$ reduction in skin severity, with no serious adverse events [76]. Additionally, a clinical trial has been initiated to evaluate the oral administration of baricitinib, which targets JAK1 and JAK2, in moderate to severe AD (NCT02576938; Table 1). Encouraging data from initial studies support the evaluation of additional JAK inhibitors for the treatment of $\mathrm{AD}$.

\section{Chemoattractant Receptor-Homologous Molecule Expressed on Th2 Cells}

Approximately $80 \%$ of patients with $\mathrm{AD}$ are sensitized to allergens, as demonstrated by increased allergen-specific IgE [24]. Subsequent exposure to these allergens triggers mast cell activation and the release of prostaglandin $\mathrm{D} 2\left(\mathrm{PGD}_{2}\right)$, which drives inflammation by engaging with its $2 \mathrm{G}$ protein-coupled receptors, $\mathrm{D}$ prostanoid receptor (DP), and chemoattractant receptor-homologous molecule expressed on Th2 cells (CRTH2) [77]. Engagement of $\mathrm{PGD}_{2}$ with CRTH2 has been implicated in the pathogenesis of allergic diseases, including $\mathrm{AD}$, by mediating the recruitment and activation of Th2 cells, innate lymphoid cells, eosinophils, and basophils [77]. Using a murine model of $\mathrm{AD}$ through ovalbumin sensitization, DP2 agonists were shown to increase eosinophil recruitment and skin inflammation through CRTH2 [78]. Additional murine studies have shown that pharmacological blockade of CRTH2 signaling can significantly reduce allergic inflammation in models of antigen-induced inflammation and AD [79-83]. Specifically, a CRTH2 antagonist inhibited $52 \%$ of ear swelling in fluorescein isothiocyanate-induced hypersensitivity in mice (a model of $\mathrm{AD}$ ) and showed good pharmacokinetic parameters in mice and rats $[82,83]$. Additionally, CRTH2 expression is increased in $\mathrm{AD}$ patients [84] and increased numbers of circulating T cells expressing CRTH2 have been shown to correlate with the severity of AD [85]. Several CRTH2 antagonists are currently under investigation for moderate to severe $\mathrm{AD}$ including QAW039 (Fevipiprant; Novartis) and OC000459 (Atopix), but the results have not been published (Table 1).

\section{Immunoglobulin E}

As elevated levels of serum IgE and allergen sensitization are found in approximately $80 \%$ of patients with $\mathrm{AD}$ [86], an allergic IgE-mediated disease pathogenesis has been historically hypothesized, by which high levels of the Th2 cytokines IL- 4 and IL-13 in AD skin lesions could influence Ig class-switching, promoting IgE production [87, 88]. Omalizumab, a humanized IgG1 monoclonal antibody against IgE, was first developed for patients with severe asthma. Given the overlapping atopic nature with asthma and increased IgE levels, omalizumab was also evaluated in patients with $\mathrm{AD}$ who were not adequately controlled with standard therapy. Several studies have evaluated omalizumab in adult and pediatric patients
76

Int Arch Allergy Immunol 2016;171:71-80 DOI: $10.1159 / 000451083$
Moreno/McPhee/Arruda/Howell 
with $\mathrm{AD}$; however, the treatment effect is inconsistent and has not provided a clear clinical benefit in all patients [89-94]. A single-center, randomized, placebo-controlled, double-blind investigation (NCT01179529) was conducted with omalizumab in 20 adult patients with severe $\mathrm{AD}$. Treatment with omalizumab reduced IgE levels, as expected, and had the added benefit of reducing pruritus. Despite these modulatory effects, omalizumab treatment did not significantly reduce skin disease severity [95]. Recently, an investigator-initiated study demonstrated that patients with severe $\mathrm{AD}$ with mutations in the FLG gene did not benefit from treatment with omalizumab, while those who lacked these mutations presented with an improvement in their skin disease severity [96]. This further illustrates the heterogeneity within $\mathrm{AD}$ and the potential role of biomarkers in identifying subpopulations of $\mathrm{AD}$ patients who could benefit from anti-IgE therapy.

Ligelizumab is a human monoclonal antibody that targets IgE with a higher affinity than omalizumab. Initial studies with ligelizumab treatment demonstrated a superior pharmacodynamic effect of IgE suppression in atopic patients, compared with omalizumab [97]. Based on these encouraging results, ligelizumab was further evaluated in more targeted atopic diseases including $\mathrm{AD}$ and allergic asthma. A randomized, double-blind, placebocontrolled trial was conducted in patients with moderate to severe AD (NCT01552629); however, subcutaneous administration of $280 \mathrm{mg}$ of ligelizumab every 2 weeks for 12 weeks did not significantly decrease the severity of $\mathrm{AD}$, as assessed by EASI50 response at week 12, compared with placebo [98]. One hypothesis for the overall lack of a significant therapeutic effect with IgE antagonism is that IgE synthesis and production are downstream of the cellular signaling pathways associated with $\mathrm{AD}$ pathogenesis, thereby limiting the effectiveness of IgE neutralization in patients with recalcitrant disease.

\section{Conclusion}

$\mathrm{AD}$ is a chronic skin disease with a high prevalence in both children and adults, and, in many cases, it constitutes the initial step in the development of other potentially severe atopic disorders. Specifically, AD is associated with a substantial patient burden that typically includes poor quality of life, sleep disturbances, and a reduction in school or work productivity [99]. Patients with $\mathrm{AD}$ were found to have lower physical vitality, social functioning, and emotional and mental health scores, compared with a psoriasis cohort [100]. Given the significant impact of $\mathrm{AD}$ on the overall quality of life of patients, there is a clear need for novel therapies that are safe and effective in the management of moderate to severe AD.

Two competing hypotheses have been suggested to describe the onset and pathogenesis of AD. The outside-in hypothesis proposes that the impaired skin barrier results from a genetic defect in epithelial cells and leads to increased allergic sensitization and AD. Many treatments for $\mathrm{AD}$ have focused on restoring the protective skin barrier to reduce the epidermal inflammation associated with the disease. These topical treatments provide transient disease resolution in patients with the milder forms, but they do not provide long-term relief for those with severe, recalcitrant disease. Additionally, these therapies fail to systemically modulate the pathways integral to disease initiation and pathogenesis [33].

The inside-out hypothesis suggests that $\mathrm{AD}$ is a systemic disease that results from an immunological abnormality, predisposing individuals to IgE-mediated sensitization. Emerging therapies provide the opportunity to systemically modulate these inflammatory pathways associated with disease pathogenesis. The varied effectiveness of treatments targeting different inflammatory pathways highlights the heterogeneity and complexity of $\mathrm{AD}$ and the need for focused therapy for this disease. As new therapies emerge for the treatment of individuals suffering from this debilitating disease, it will be important to further characterize the heterogeneity of patients in an effort to delineate the populations that will benefit from targeted therapy. Specifically, it is widely agreed that the central event in the pathogenesis of $\mathrm{AD}$ is the activation of the Th2 cytokine axis that results in an increased inflammatory response, disruption of the skin barrier, increased susceptibility to infections, and increased allergen sensitization. Novel therapies, such as those described here, that target the Th2 signaling axis, have the potential to revolutionize the management of $\mathrm{AD}$ by introducing less harmful and more effective treatment strategies.

\section{Acknowledgment}

We thank Drs. Koustubh Ranade, Edward Piper, Christopher Kell and Rene Van der Merwe at MedImmune for their helpful comments and discussions. We are grateful to Sepideh Farshadi for her graphic design expertise in generating Figure 1. The content of the article is solely the responsibility of the authors and does not necessarily represent the official views of the University of São Paulo or MedImmune, LLC. 


\section{Author Contributions}

All authors have contributed to the preparation, drafting, reviewing, and approval of this paper.

\section{Disclosure Statement}

Roderick McPhee and Michael Howell are full-time employees and share-holders of AstraZeneca/MedImmune.

\section{References}

1 Weidinger S, Novak N: Atopic dermatitis. Lancet 2015;387:1109-1122.

2 Silverberg JI, Silverberg NB: Atopic dermatitis: update on pathogenesis and comorbidities. Curr Dermatol Rep 2012;1:168-178.

3 Silverberg JI, Hanifin JM: Adult eczema prevalence and associations with asthma and other health and demographic factors: a US population-based study. J Allergy Clin Immunol 2013;132:1132-1138.

4 Shaw TE, Currie GP, Koudelka CW, Simpson EL: Eczema prevalence in the United States: data from the 2003 National Survey of Children's Health. J Invest Dermatol 2011;131: 67-73.

5 Hanifin JM, Reed ML: A population-based survey of eczema prevalence in the United States. Dermatitis 2007;18:82-91.

6 Bieber T: Atopic dermatitis. N Engl J Med 2008;358:1483-1494.

7 Bannister MJ, Freeman S: Adult-onset atopic dermatitis. Australas J Dermatol 2000;41: 225-228.

8 Ozkaya E: Adult-onset atopic dermatitis. J Am Acad Dermatol 2005;52:579-582.

9 Dharmage SC, Lowe AJ, Matheson MC, Burgess JA, Allen KJ, Abramson MJ: Atopic dermatitis and the atopic march revisited. Allergy 2014;69:17-27.

10 Tsakok T, Marrs T, Mohsin M, Baron S, Du Toit G, Till S, Carsten F: Does atopic dermatitis cause food allergy? A systematic review. J Allergy Clin Immunol 2016;137:1071-1078.

11 Abuabara K, Margolis DJ: Do children really outgrow their eczema, or is there more than one eczema? J Allergy Clin Immunol 2013; 132:1139-1140.

12 Martinez FD: New insights into the natural history of asthma: primary prevention on the horizon. J Allergy Clin Immunol 2011;128: 939--945.

13 Kattan J: The prevalence and natural history of food allergy. Curr Allergy Asthma Rep 2016;16:47.

14 Lee E, Lee SH, Kwon J-W, Kim Y, Cho HJ, Yang SI, Jung YH, Kim HY, Seo JH, Kim BJ, Kim HB, Lee SY, Kwon HJ, Hong SJ: Atopic dermatitis phenotype with early onset and high serum IL-13 is linked to the new development of bronchial hyperresponsiveness in school children. Allergy 2016;71:692700 .

15 Loo EX, Shek LP, Goh A, Teoh OH, Chan YH, Soh SE, Saw SM, Kwek K, Gluckman PD,
Godfrey KM, Chong YS, Lee BW, Van Bever HP: Atopic dermatitis in early life: evidence for at least three phenotypes? Results from the GUSTO Study. Int Arch Allergy Immunol 2015;166:273-279.

16 van der Hulst AE, Klip H, Brand PLP: Risk of developing asthma in young children with atopic eczema: a systematic review. J Allergy Clin Immunol 2007;120:565-569.

17 von Kobyletzki LB, Bornehag CG, Hasselgren M, Larsson M, Lindström CB, Svensson Å: Eczema in early childhood is strongly associated with the development of asthma and rhinitis in a prospective cohort. BMC Dermatol 2012;12:11.

18 Weidinger S, Willis-Owen SAG, Kamatani Y, Baurecht H, Morar N, Liang L, et al: A genome-wide association study of atopic dermatitis identifies loci with overlapping effects on asthma and psoriasis. Hum Mol Genet 2013;22:4841-4856.

19 Zheng T, Yu J, Oh MH, Zhu Z: The atopic march: progression from atopic dermatitis to allergic rhinitis and asthma. Allergy Asthma Immunol Res 2011;3:67-73.

20 Fishbein AB, Vitaterna O, Haugh IM, Bavishi AA, Zee PC, Turek FW, Sheldon SH, Silverberg JI, Paller AS: Nocturnal eczema: review of sleep and circadian rhythms in children with atopic dermatitis and future research directions. J Allergy Clin Immunol 2015;136: $1170-1177$.

21 Blome C, Radtke MA, Eissing L, Augustin M: Quality of life in patients with atopic dermatitis: disease burden, measurement, and treatment benefit. Am J Clin Dermatol 2016;17: 163-169.

22 Simpson EL, Bieber T, Eckert L, Wu R, Ardeleanu M, Graham NMH, Pirozzi G, Mastey V: Patient burden of moderate to severe atopic dermatitis $(\mathrm{AD})$ : Insights from a phase $2 \mathrm{~b}$ clinical trial of dupilumab in adults. $J$ Am Acad Dermatol 2016;74:491-498.

23 Mansouri Y, Guttman-Yassky E: Immune pathways in atopic dermatitis, and definition of biomarkers through broad and targeted therapeutics. J Clin Med 2015;4:858-873.

24 Howell MD, Parker ML, Mustelin T, Ranade $\mathrm{K}$ : Past, present, and future for biologic intervention in atopic dermatitis. Allergy 2015;70: 887-896.

25 Malajian D, Guttman-Yassky E: New pathogenic and therapeutic paradigms in atopic dermatitis. Cytokine 2015;73:311-318.
26 Irvine AD, McLean WHI, Leung DYM: Filaggrin mutations associated with skin and allergic diseases. N Engl J Med 2011;365:13151327.

27 Thyssen JP, Kezic S: Causes of epidermal filaggrin reduction and their role in the pathogenesis of atopic dermatitis. J Allergy Clin Immunol 2014;134:792-799.

28 Linneberg A, Fenger R V, Husemoen LL, Thuesen BH, Skaaby T, Gonzalez-Quintela A, Vidal C, Carlsen BC, Johansen JD, Menné T, Stender S, Melgaard M, Szecsi PB, Berg ND, Thyssen JP: Association between loss-offunction mutations in the filaggrin gene and self-reported food allergy and alcohol sensitivity. Int Arch Allergy Immunol 2013;161: 234-242.

29 Cabanillas B, Novak N: Atopic dermatitis and filaggrin. Curr Opin Immunol 2016;17:42: $1-8$

30 Otsuka A, Doi H, Egawa G, Maekawa A, Fujita T, Nakamizo S, Nakashima C, Nakajima S, Watanabe T, Miyachi Y, Narumiya S, Kabashima K, et al: Possible new therapeutic strategy to regulate atopic dermatitis through upregulating filaggrin expression. J Allergy Clin Immunol 2014;133:139-146.

31 Amano W, Nakajima S, Kunugi H, Numata $Y$, Kitoh A, Egawa G, Dainichi T, Honda T, Otsuka A, Kimoto Y, Yamamoto Y, Tanimoto A, Matsushita M, Miyachi Y, Kabashima K: The Janus kinase inhibitor JTE-052 improves skin barrier function through suppressing signal transducer and activator of transcription 3 signaling. J Allergy Clin Immunol 2015;136: 667-677.

32 Ming M, Zhao B, Shea CR, Shah P, Qiang L, White SR, Sims DM, He YY: Loss of sirtuin 1 (SIRT1) disrupts skin barrier integrity and sensitizes mice to epicutaneous allergen challenge. J Allergy Clin Immunol 2015;135:936945.

33 Lio PA, Lee M, LeBovidge J, Timmons KG, Schneider L: Clinical management of atopic dermatitis: practical highlights and updates from the Atopic Dermatitis Practice Parameter 2012. J Allergy Clin Immunol Pract 2014; 2:361-369.

34 Di Filippo P, Scaparrotta A, Rapino D, Cingolani A, Attanasi M, Petrosino MI, Chuang K, Di Pillo S, Chiarelli F: Vitamin D supplementation modulates the immune system and improves atopic dermatitis in children. Int Arch Allergy Immunol 2015;166:91-96. 
35 Ring J, Alomar A, Bieber T, Deleuran M, Fink-Wagner A, Gelmetti C, Gieler U, Lipozencic J, Luger T, Oranje AP, Schäfer T, Schwennesen T, Seidenari S, Simon D, Ständer S, Stingl G, Szalai S, Szepietowski JC, Taïeb A, Werfel T, Wollenberg A, Darsow U; European Dermatology Forum; European Academy of Dermatology and Venereology; European Task Force on Atopic Dermatitis; European Federation of Allergy; European Society of Pediatric Dermatology; Global Allergy and Asthma European Network: Guidelines for treatment of atopic eczema (atopic dermatitis) part I. J Eur Acad Dermatol Venereol 2012;26:1045-1060

36 Chi CC, Kirtschig G, Aberer W, Gabbud JP, Lipozenčić J, Kárpáti S, Haustein UF, Zuberbier T, Wojnarowska F: Evidence-based (S3) guideline on topical corticosteroids in pregnancy. Br J Dermatol 2011;165:943-952.

37 Boguniewicz M: Atopic dermatitis: the updated practice parameter and beyond. Allergy Asthma Proc 2014;35:429-434.

38 Proudfoot LE, Powell AM, Ayis S, Barbarot S, Baselga Torres E, Deleuran M, Fölster-Holst R, Gelmetti C, Hernández-Martin A, Middelkamp-Hup MA, Oranje AP, Logan K, Perkin M, Patrizi A, Rovatti G, Schofield O, Spuls P, Svensson Å, Vestergaard C, Wahlgren CF, Schmitt J, Flohr C; European Dermato-Epidemiology Network (EDEN): The European Treatment of Severe Atopic Eczema in Children Taskforce (TREAT) survey. Br J Dermatol 2013;169:901-909.

39 Leung DYM, Boguniewicz M, Howell MD, Nomura I, Hamid QA: New insights into atopic dermatitis. J Clin Invest 2004;113:651657.

40 Gittler JK, Shemer A, Suárez-Fariñas M, Fuentes-Duculan J, Gulewicz KJ, Wang CQ, Mitsui H, Cardinale I, de Guzman Strong C, Krueger JG, Guttman-Yassky E: Progressive activation of $\mathrm{T}(\mathrm{h}) 2 / \mathrm{T}(\mathrm{h}) 22$ cytokines and selective epidermal proteins characterizes acute and chronic atopic dermatitis. J Allergy Clin Immunol 2012;130:1344-1354.

41 Nomura I, Goleva E, Howell MD, Hamid QA, Ong PY, Hall CF, Darst MA, Gao B, Boguniewicz M, Travers JB, Leung DY: Cytokine milieu of atopic dermatitis, as compared to psoriasis, skin prevents induction of innate immune response genes. J Immunol 2003 171:3262-3269.

42 Jeong CW, Ahn KS, Rho NK, Park YD, Lee DY, Lee JH, Lee ES, Yang JM: Differential in vivo cytokine mRNA expression in lesional skin of intrinsic versus extrinsic atopic dermatitis patients using semiquantitative RTPCR. Clin Exp Allergy 2003;33:1717-1724.

43 Teraki Y, Sakurai A, Izaki S: IL-13/IL-22-coproducing $\mathrm{T}$ cells, a novel subset, are increased in atopic dermatitis. J Allergy Clin Immunol 2013;132:971-974

44 Czarnowicki T, Gonzalez J, Shemer A, Malajian D, Xu H, Zheng X, Khattri S, Gilleaudeau
$\mathrm{P}$, Sullivan-Whalen $\mathrm{M}$, Suárez-Fariñas $\mathrm{M}$, Krueger JG, Guttman-Yassky E: Severe atopic dermatitis is characterized by selective expansion of circulating $\mathrm{TH} 2 / \mathrm{TC} 2$ and $\mathrm{TH} 22 /$ TC22, but not TH17/TC17, cells within the skin-homing T-cell population. J Allergy Clin Immunol 2015;136:104-115.

45 Chan LS, Robinson N, Xu L: Expression of interleukin-4 in the epidermis of transgenic mice results in a pruritic inflammatory skin disease: an experimental animal model to study atopic dermatitis. J Invest Dermatol 2001;117:977-983.

46 Zheng T, Oh MH, Oh SY, Schroeder JT, Glick $\mathrm{AB}$, Zhu Z: Transgenic expression of interleukin-13 in the skin induces a pruritic dermatitis and skin remodeling. J Invest Dermatol 2008; 129:742-751.

47 Lee GR, Flavell RA: Transgenic mice which overproduce Th2 cytokines develop spontaneous atopic dermatitis and asthma. Int Immunol 2004;16:1155-1160.

48 Sehra S, Yao Y, Howell MD, Nguyen ET, Kansas GS, Leung DY, Travers JB, Kaplan MH: IL-4 regulates skin homeostasis and the predisposition toward allergic skin inflammation. J Immunol 2010;184:3186-3190.

49 Howell MD, Kim BE, Gao P, Grant A V, Boguniewicz $\mathrm{M}$, Debenedetto $\mathrm{A}$, Schneider $\mathrm{L}$, Beck LA, Barnes KC, Leung DY: Cytokine modulation of atopic dermatitis filaggrin skin expression. J Allergy Clin Immunol 2007;120: 150-155.

50 Kim BE, Leung DYM, Boguniewicz M, Howell MD: Loricrin and involucrin expression is down-regulated by Th2 cytokines through STAT-6. Clin Immunol 2008;126:332-337.

51 Howell MD, Fairchild HR, Kim BE, Bin L, Boguniewicz M, Redzic JS, Hansen KC, Leung DY: Th2 cytokines act on S100/A11 to downregulate keratinocyte differentiation. J Invest Dermatol 2008;128:2248-2258.

52 De Benedetto A, Rafaels NM, McGirt LY, Ivanov AI, Georas SN, Cheadle C, Berger AE, Zhang K, Vidyasagar S, Yoshida T, Boguniewicz M, Hata T, Schneider LC, Hanifin JM, Gallo RL, Novak N, Weidinger S, Beaty TH, Leung DY, Barnes KC, Beck LA: Tight junction defects in patients with atopic dermatitis. J Allergy Clin Immunol 2011;127:773-786.

53 Ong PY, Ohtake T, Brandt C, Strickland I, Boguniewicz M, Ganz T, Gallo RL, Leung DY: Endogenous antimicrobial peptides and skin infections in atopic dermatitis. N Engl J Med 2002;347:1151-1160.

54 Albanesi C, Fairchild HR, Madonna S, Scarponi $\mathrm{C}$, De Pità $\mathrm{O}$, Leung $\mathrm{DY}$, Howell $\mathrm{MD}$ : IL-4 and IL-13 negatively regulate TNF-alpha- and IFN-gamma-induced beta-defensin expression through STAT-6, suppressor of cytokine signaling (SOCS)-1, and SOCS-3. J Immunol 2007;179:984-992.

55 Howell MD, Wollenberg A, Gallo RL, Flaig M, Streib JE, Wong C, Pavicic T, Boguniewicz M, Leung DY: Cathelicidin deficiency predis- poses to eczema herpeticum. J Allergy Clin Immunol 2006;117:836-841.

56 Brauweiler AM, Goleva E, Leung DY: Th2 cytokines increase Staphylococcus aureus alpha toxin-induced keratinocyte death through the signal transducer and activator of transcription 6 (STAT6). J Invest Dermatol 2014;134: 2114-2121.

57 Burmeister Getz E, Fisher DM, Fuller R: Human pharmacokinetics/pharmacodynamics of an interleukin-4 and interleukin-13 dual antagonist in asthma. J Clin Pharmacol 2009; 49:1025-1036.

58 Antoniu SA: Pitrakinra, a dual IL-4/IL-13 antagonist for the potential treatment of asthma and eczema. Curr Opin Investig Drugs 2010; 11:1286-1294

59 Beck LA, Thaçi D, Hamilton JD, Graham NM, Bieber T, Rocklin R, Ming JE, Ren $\mathrm{H}$, Kao R, Simpson E, Ardeleanu M, Weinstein SP, Pirozzi G, Guttman-Yassky E, SuárezFariñas M, Hager MD, Stahl N, Yancopoulos GD, Radin AR: Dupilumab treatment in adults with moderate-to-severe atopic dermatitis. N Engl J Med 2014;371:130-139.

60 Thaçi D, Simpson EL, Beck LA, Bieber T, Blauvelt A, Papp K, Soong W, Worm M, Szepietowski JC, Sofen H, Kawashima M, Wu R, Weinstein SP, Graham NM, Pirozzi G, Teper A, Sutherland ER, Mastey V, Stahl N, Yancopoulos GD, Ardeleanu M: Efficacy and safety of dupilumab in adults with moderateto-severe atopic dermatitis inadequately controlled by topical treatments: a randomised, placebo-controlled, dose-ranging phase $2 \mathrm{~b}$ trial. Lancet 2015;387:40-52.

61 Simon D, Braathen LR, Simon HU: Eosinophils and atopic dermatitis. Allergy 2004;59: 561-570.

62 Molfino NA, Gossage D, Kolbeck R, Parker JM, Geba GP: Molecular and clinical rationale for therapeutic targeting of interleukin-5 and its receptor. Clin Exp Allergy 2012;42:712737.

63 Liu FT, Goodarzi H, Chen HY: IgE, mast cells, and eosinophils in atopic dermatitis. Clin Rev Allergy Immunol 2011;41:298-310.

64 Spergel JM, Mizoguchi E, Oettgen H, Bhan AK, Geha RS: Roles of TH1 and TH2 cytokines in a murine model of allergic dermatitis. J Clin Invest 1999;103:1103-1111.

65 Oldhoff JM, Darsow U, Werfel T, Katzer K, Wulf A, Laifaoui J, Hijnen DJ, Plötz S, Knol EF, Kapp A, Bruijnzeel-Koomen CA, Ring J, de Bruin-Weller MS: Anti-IL-5 recombinant humanized monoclonal antibody (mepolizumab) for the treatment of atopic dermatitis. Allergy 2005;60:693-696.

66 Oldhoff JM, Darsow U, Werfel T, Bihari IC, Katzer K, Laifaoui J, Plötz S, Kapp A, Knol EF, Bruijnzeel-Koomen CA, Ring J, de BruinWeller MS: No effect of anti-interleukin-5 therapy (mepolizumab) on the atopy patch test in atopic dermatitis patients. Int Arch Allergy Immunol 2006;141:290-294. 
67 Comeau MR, Ziegler SF: The influence of TSLP on the allergic response. Mucosal Immunol 2010;3:138-147.

68 Soumelis V, Reche PA, Kanzler H, Yuan W, Edward G, Homey B, Gilliet M, Ho S, Antonenko S, Lauerma A, Smith K, Gorman D, Zurawski S, Abrams J, Menon S, McClanahan T, de Waal-Malefyt Rd R, Bazan F, Kastelein RA, Liu YJ: Human epithelial cells trigger dendritic cell mediated allergic inflammation by producing TSLP. Nat Immunol 2002;3: 673-680.

69 Wang Y, Liu Y: Thymic stromal lymphopoietin, OX40-ligand, and interleukin-25 in allergic responses. Clin Exp Allergy 2009;39: 798-806.

70 Yoo J, Omori M, Gyarmati D, Zhou B, Aye T, Brewer A, Comeau MR, Campbell DJ, Ziegler SF: Spontaneous atopic dermatitis in mice expressing an inducible thymic stromal lymphopoietin transgene specifically in the skin. J Exp Med 2005;202:541-549.

71 He R, Oyoshi MK, Garibyan L, Kumar L, Ziegler SF, Geha RS: TSLP acts on infiltrating effector T cells to drive allergic skin inflammation. Proc Natl Acad Sci USA 2008; 105 : 11875-11880.

72 Jessup HK, Brewer AW, Omori M, Rickel EA, Budelsky AL, Yoon BR, Ziegler SF, Comeau MR: Intradermal administration of thymic stromal lymphopoietin induces a $\mathrm{T}$ cell and eosinophil-dependent systemic Th2 inflammatory response. J Immunol 2008; 181:43114319.

73 Wilson SR, Thé L, Batia LM, Beattie K, Katibah GE, McClain SP, Pellegrino M, Estandian DM, Bautista DM: The epithelial cell-derived atopic dermatitis cytokine TSLP activates neurons to induce itch. Cell 2013;155:285295.

74 Gandhi NA, Bennett BL, Graham NMH, Pirozzi G, Stahl N, Yancopoulos GD: Targeting key proximal drivers of type 2 inflammation in disease. Nat Rev Drug Discov 2015;15: $35-50$.

75 Rochman Y, Kashyap M, Robinson GW, Sakamoto K, Gomez-Rodriguez J, Wagner KU, Leonard WJ: Thymic stromal lymphopoietin-mediated STAT5 phosphorylation via kinases JAK1 and JAK2 reveals a key difference from IL-7-induced signalling. Proc Natl Acad Sci USA 2010;107:19455-19460.

76 Levy LL, Urban J, King BA: Treatment of recalcitrant atopic dermatitis with the oral Janus kinase inhibitor tofacitinib citrate. J Am Acad Dermatol 2015;73:395-399.

77 Kostenis E, Ulven T: Emerging roles of DP and CRTH2 in allergic inflammation. Trends Mol Med 2006;12:148-158.

78 Spik I, Brénuchon C, Angéli V, Staumont D, Fleury S, Capron M, Trottein F, Dombrowicz $D$ : Activation of the prostaglandin D2 receptor DP2/CRTH2 increases allergic inflammation in mouse. J Immunol 2005; 174:37033708.
79 Chevalier E, Stock J, Fisher T, Dupont M, Fric M, Fargeau H, Leport M, Soler S, Fabien S, Pruniaux MP, Fink M, Bertrand CP, McNeish J, Li B: Cutting edge: chemoattractant receptor-homologous molecule expressed on Th2 cells plays a restricting role on IL-5 production and eosinophil recruitment. J Immunol 2005; 175:2056-2060.

80 Satoh T, Moroi R, Aritake K, Urade Y, Kanai Y, Sumi K, Yokozeki H, Hirai H, Nagata K, Hara T, Utsuyama M, Hirokawa K, Sugamura K, Nishioka K, Nakamura M: Prostaglandin D2 plays an essential role in chronic allergic inflammation of the skin via CRTH2 receptor. J Immunol 2006;177:2621-2629.

81 Oiwa M, Satoh T, Watanabe M, Niwa H, Hirai H, Nakamura M, Yokozeki H: CRTH2-dependent, STAT6-independent induction of cedar pollen dermatitis. Clin Exp Allergy 2008;38:1357-1366.

82 Boehme SA, Chen EP, Franz-Bacon K, Sásik R, Sprague LJ, Ly TW, Hardiman G, Bacon KB: Antagonism of CRTH2 ameliorates chronic epicutaneous sensitization-induced inflammation by multiple mechanisms. Int Immunol 2009;21:1-17.

83 Boehme SA, Franz-Bacon K, Chen EP, Sásik R, Sprague LJ, Ly TW, Hardiman G, Bacon KB: A small molecule CRTH2 antagonist inhibits FITC-induced allergic cutaneous inflammation. Int Immunol 2009:21:81-93.

84 Hijnen D, Nijhuis E, Bruin-Weller M, Holstege F, Koerkamp MG, Kok I, BruijnzeelKoomen C, Knol E: Differential expression of genes involved in skin homing, proliferation, and apoptosis in CD4+ T cells of patients with atopic dermatitis. J Invest Dermatol 2005; 125 : 1149-1155.

85 Iwasaki M, Nagata K, Takano S, Takahashi K, Ishii N, Ikezawa Z: Association of a new-type prostaglandin D2 receptor CRTH2 with circulating Thelper 2 cells in patients with atopic dermatitis. J Invest Dermatol 2002;119: 609-616.

86 Novak N, Bieber T: Allergic and nonallergic forms of atopic diseases. J Allergy Clin Immunol 2003; 112:252-262.

87 Oettgen HC, Geha RS: IgE in asthma and atopy: cellular and molecular connections. J Clin Invest 1999;104:829-835.

88 Poulsen LK, Hummelshoj L: Triggers of IgE class switching and allergy development. Ann Med 2007:39:440-456.

89 Denby KS, Beck LA: Update on systemic therapies for atopic dermatitis. Curr Opin Allergy Clin Immunol 2012;12:421-426.

90 Krathen RA, Hsu S: Failure of omalizumab for treatment of severe adult atopic dermatitis. J Am Acad Dermatol 2005;53:338-340.

91 Iyengar SR, Hoyte EG, Loza A, Bonaccorso S, Chiang D, Umetsu DT, Nadeau KC: Immunologic effects of omalizumab in children with severe refractory atopic dermatitis: a randomized, placebo-controlled clinical trial. Int Arch Allergy Immunol 2013;162:89-93.
92 Sheinkopf LE, Rafi AW, Do LT, Katz RM, Klaustermeyer WB: Efficacy of omalizumab in the treatment of atopic dermatitis: a pilot study. Allergy Asthma Proc 2008;29:530537.

93 Park SY, Choi MR, Na JI, Youn SW, Park $\mathrm{KC}, \mathrm{Huh} \mathrm{CH}$ : Recalcitrant atopic dermatitis treated with omalizumab. Ann Dermatol 2010;22:349-352.

94 Belloni B, Ziai M, Lim A, Lemercier B, Sbornik M, Weidinger S, Andres C, Schnopp C, Ring J, Hein R, Ollert M, Mempel M: Lowdose anti-IgE therapy in patients with atopic eczema with high serum IgE levels. J Allergy Clin Immunol 2007;120:1223-1225.

95 Heil PM, Maurer D, Klein B, Hultsch T, Stingl G: Omalizumab therapy in atopic dermatitis: depletion of IgE does not improve the clinical course - a randomized, placebocontrolled and double blind pilot study. J Dtsch Dermatol Ges 2010;8:990-998.

96 Hotze M, Baurecht H, Rodríguez E, Chapman-Rothe N, Ollert M, Fölster-Holst R, Adamski J, Illig T, Ring J, Weidinger S: Increased efficacy of omalizumab in atopic dermatitis patients with wild-type filaggrin status and higher serum levels of phosphatidylcholines. Allergy 2014;69:132-135.

97 Arm JP, Bottoli I, Skerjanec A, Floch D, Groenewegen A, Maahs S, Owen CE, Jones I, Lowe PJ: Pharmacokinetics, pharmacodynamics and safety of QGE031 (ligelizumab), a novel high-affinity anti-IgE antibody, in atopic subjects. Clin Exp Allergy 2014;44: 1371-1385.

98 Novartis Clinical Trial No. CQGE031X2201. http://www.novctrd.com (accessed March 15, 2016).

99 Ando T, Hashiro M, Noda K, Adachi J, Hosoya R, Kamide R, Ishikawa T, Komaki G: Development and validation of the psychosomatic scale for atopic dermatitis in adults. J Dermatol 2006;33:439-450.

100 Kiebert G, Sorensen S V., Revicki D, Fagan SC, Doyle JJ, Cohen J, Fivenson D: Atopic dermatitis is associated with a decrement in health-related quality of life. Int J Dermatol 2002;41:151-158.

101 Sheldon E, Schwickart M, Li J, Kim K, Crouch S, Parveen S, Kell C, Birrell C: Pharmacokinetics, pharmacodynamics, and safety of MEDI4212, an anti-IgE monoclonal antibody, in subjects with atopy: a phase I study. Adv Ther 2016;33:225-251.

102 Simpson EL, Gadkari A, Worm M, Soong W, Blauvelt A, Eckert L, Wu R, Ardeleanu M, Graham NM, Pirozzi G, Sutherland ER, Mastey V: Dupilumab therapy provides clinically meaningful improvement in patientreported outcomes (PROs): a phase IIb, randomized, placebo-controlled, clinical trial in adult patients with moderate to severe atopic dermatitis (AD). J Am Acad Dermatol 2016;75:506-515. 